\title{
From Brexit to Bregret
}

\section{GORDANA LALIĆ-KRSTIN AND NADEŽDA SILAŠKI}

\author{
An account of some Brexit-induced neologisms in English
}

\section{Introduction}

The UK's June 2016 decision to withdraw from the European Union, popularly referred to as Brexit, has had a major political, financial and economic impact worldwide. However, the impact was also linguistic as this event has generated a myriad of neologisms in English, such as breferendum, brexiteer, Brexitsphere, regrexit or Brexitology. The aim of the present study is to give a general overview of these new words, to establish the predominant word-formational patterns as well as to point out the creativity and speed with which speakers of English have reacted linguistically to this change in the socio-political context.

Linguistically speaking, the word Brexit, documented as early as 2012, is thought to be modelled after Grexit (Greece/Greek + exit), 'a term which had appeared earlier in the year in reference to the possibility of Greece leaving the Eurozone' (Maxwell, 2016). After its relatively short co-existence with Brixit, another novel blend coined to refer to the same event, Brexit has now established itself as a household word in the English lexicon. It was shortlisted by Oxford Dictionaries as The Word of the Year in both 2014 and 2015 and was later entered into their online dictionary and defined there, prior to the actual referendum, as 'a term for the potential or hypothetical departure of the United Kingdom from the European Union', ${ }^{1}$ which may indicate its relatively quick conventionalization, lexicalization and institutionalization in the English language. As Leyland (2016) points out, '[t]he speed with which it became widely used and recognized was impressive, fuelled by the fact it filled an empty space in our language, and the growing importance of the phenomenon it described'. Following the appearance of Brexit, and induced by the events closely preceding and following the British referendum, held on June 23, 2016, as well as the public perception of the impact of the UK's subsequent decision to leave the EU, a multitude of other creative coinages appeared as a result, many of them using Brexit either as a model, a source word, or merely as an inspiration for other creative coinages.

After this brief introduction, in the next section we deal with the material used for the analysis and its compilation, after which we respectively look at and discuss the neologisms which have been created using (1) Brexit as a model, (2) Brexit as a source word, and (3) Brexit as an inspiration. In the penultimate section of the paper we discuss some of the main reasons for linguistic

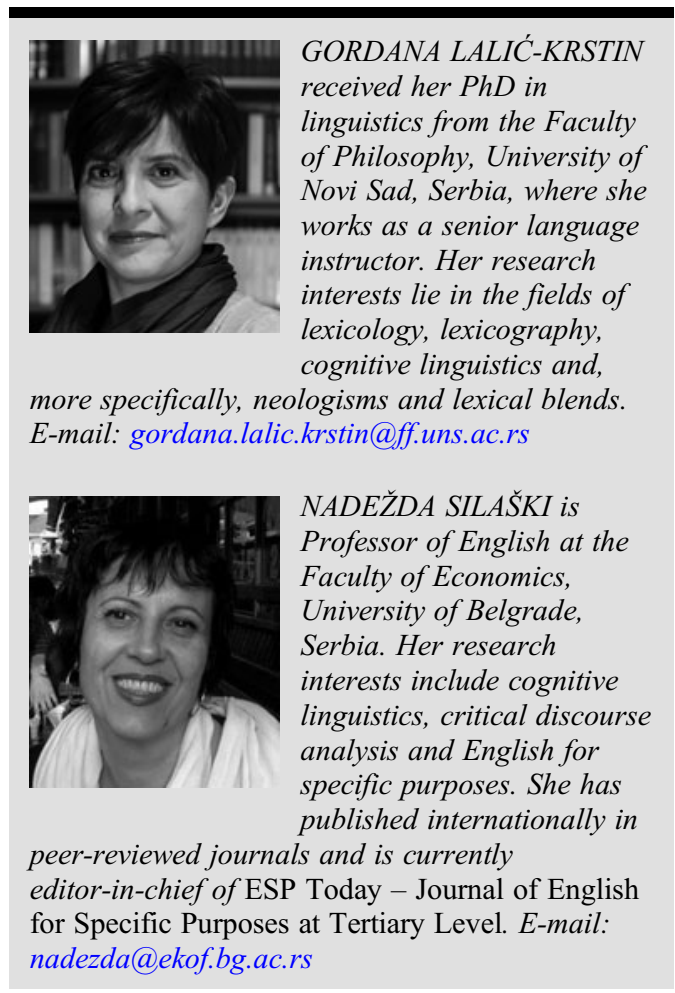


creativity, especially those which can account for linguistic creativity triggered by Brexit. Finally, we offer some concluding remarks.

\section{Material}

The material for our analysis was compiled in the period from June to November 2016 (closely preceding and following the June 23 referendum) from various sources: news media (broadcast and online), social media such as Facebook and Twitter, blogs and internet forums. We also examined available photographs and videos taken during some of the pro-Brexit and pro-EU protests held in the UK around the time of the referendum in search of any new Brexit-related words. From the diverse data we collected, we were able to isolate exit, leave, remain, Britain and $E U$ as the most frequent source words in the formation of Brexit-induced neologisms. This, of course, does not come as a surprise as the semantic opposition of exit/leave vs. remain and the perceived sociopolitical opposition of Britain vs. EU constitute key elements in the conceptualization of Brexit. Therefore, the focus of this paper will be on those Brexit-induced neologisms, 71 in total, whose source words are exit, leave, remain, Britain and $E U$, but also on neologisms formed according to analogy with Brexit (e.g. Germexit, Portugexit) or inspired by it (Departugal, Italeave). Needless to say, this list is not exhaustive as surely there are words that have escaped us. However, we believe it represents an illustrative sample of linguistic tendencies in the formation of neologisms related to this sensitive period of British history.

Some of the words are clearly here to stay whereas others will surely be soon forgotten, failing to make a lasting contribution to the English word stock. And while predicting their failure or success can be a challenging and insightful linguistic endeavour (see, for example, Metcalf, 2002), no such attempts will be made in this paper. Our aim is merely to record those neologisms, believing, as Štekauer (2002) does, that whether a word

will be spread over the whole speech community

$[\ldots]$ or whether it will be confined to a single use on the part of a single speaker is insignificant. What is important is that language has demonstrated its productive capacity to generate a new, well-formed linguistic sign by means of its productive Word-Formation Rules whenever the need arises (Štekauer, 2002: 101).

\section{Brexit as a model}

As already mentioned, Brexit was modelled after Grexit, a word coined to denote the possibility of Greece leaving the Eurozone, ${ }^{2}$ giving rise to at least two more similarly coined blends, Spexit and Itexit, referring to the prospect of the same event in Spain and Italy. However, as the UK referendum approached and the media coverage intensified, building up suspense, new words proliferated in a matter of days to name hypothetical scenarios in other EU countries. For a while it seemed that there was a real craze on the internet as to who would come up with the most imaginative word (see, for example, Zwicky, 2016; comments in Liberman, 2015a, 2015b, 2016), which in some cases resulted in more than one word for the same country and more often than not in some very creative and associative coinages, as can be seen in Table $1 .^{3}$

In the aftermath of the UK referendum, riding a wave of increased public interest in the topic and familiarity with the word Brexit, even more new blends were coined. Very soon the wordformational pattern was generalized and the meaning extended from that of 'Britain leaving the EU' to that of 'any country leaving a political union', as evidenced by Calexit [California + exit] 'California leaving the US', Texit [Texas + exit] 'Texas leaving the US' and Scexit/Scoxit [Scotland+exit]

Table 1: Hypothetical scenarios of other countries leaving the EU, modelled upon Brexit

\begin{tabular}{|c|c|}
\hline Auxit & [Austria + exit] \\
\hline Bexit & [Belgium + exit] \\
\hline Chexit / Czechit & {$[$ Czech + exit $]$} \\
\hline Dexit & [Deutschland + exit] \\
\hline Fixit & [Finland + exit] \\
\hline Frexit & {$[$ France + exit $]$} \\
\hline Germexit / Gerxit & [Germany + exit] \\
\hline Irelexit / Irexit & [Ireland + exit] \\
\hline Italexit / Itexit & {$[$ Italy + exit $]$} \\
\hline Luxembexit & [Luxembourg + exit] \\
\hline Nexit & [Netherlands + exit] \\
\hline Oexit & [Österreich+ exit] \\
\hline $\begin{array}{l}\text { Pexit / Portexit / } \\
\text { Portugexit / Portuxit }\end{array}$ & [Portugal + exit] \\
\hline
\end{tabular}


'Scotland leaving the UK'. Several other words we have recorded indicate that the meaning has been even further generalized to include not only countries but other entities, e.g. Mexit [Messi+exit] 'Lionel Messi's retirement from international football'; Rexit [Rajan + exit] 'Raghuram Rajan's stepping down from the Royal Bank of India'; Trexit [Trump + exit] 'exit from the US on account of Donald Trump'; and Zumxit [Zuma+exit] 'a potential resignation of South Africa's President Jacob Zuma'. Indeed, Brexit itself has been used on occasion to mean 'any exit by someone/something related to Britain', as in a headline from Los Angeles Times about Andy Murray, a British tennis player: No 'Brexit' for Andy Murray, who wins second Wimbledon title in 4 years (Farmer, 2016).

\section{Brexit as a source word}

From the point of view of its word-formation, Brexit can be interpreted as having been coined from either Britain + exit or from British + exit, the latter interpretation being more prevalent (see Brexit entries in OED, 2016; Cambridge Dictionary, 2016; Collins, 2017; but also Quinion, 2013; Liberman, 2015a; Fontaine, 2017). Similarly, with quite a few newly formed blends, it is equally unclear whether the first source word is Britain, British or Brexit, as for instance in breferendum, Brexpats or (point of no) Breturn. Clear cases include suffixations such as brexiter, brexiteer or Brexitesque and neoclassical compounds Brexitography, Brexitology or Brexitophobia.

Looking at what word-formation processes were applied to coin the Brexit words, there is a strikingly high number of blends (Table 2). Lexical blending has gone from being a sporadic wordformation process (Aronoff, 1976: 21) that 'has apparently not led to the coining of many common words' (Marchand, 1969: 367) to being one of the currently most productive mechanisms for creating new words, as many authors have pointed out (Algeo, 1977: 74; Bauer, 1994: 37-39; Bryant, 1974: 164; Cannon, 1986: 737, 2000: 956; Crystal, 1995: 130; Katamba, 1994: 184; Kemmer, 2003: 69-70; Lehrer, 2006: 590; Stockwell \& Minkova, 2001: 6; Szymanek 2005: 434). While it does not come as a surprise that there are so many, one thing is unusual. Blends are rarely used to form other blends as their interpretation would potentially be quite difficult. Here, however, we have a blend, Brexit, used recurrently to coin a whole series of new blends, whose interpretation does not seem to be impeded in any way. The fact that
Table 2: Brexit as a source word in blends ${ }^{4}$

\begin{tabular}{|c|c|}
\hline (point of no) Breturn & Brexit + (point of no) return \\
\hline Borexit & Boris + exit \\
\hline bracceptance & Brexit + acceptance \\
\hline Braccident & Brexit + accident \\
\hline Branalysis & Brexit + analysis \\
\hline Branger & Brexit + anger \\
\hline Brant & Brexit + rant \\
\hline brargaining & Brexit + bargaining \\
\hline bredictable & Brexit + predictable \\
\hline Bre-do & Brexit + redo \\
\hline breferendum & Brexit + referendum \\
\hline Bregret & Brexit + regret \\
\hline Brelax & Brexit + relax \\
\hline bremain & Brexit + remain \\
\hline bremorse & Brexit + remorse \\
\hline Brenial & Brexit + denial \\
\hline Brepeat & Brexit + repeat \\
\hline brepression & Brexit + depression \\
\hline bresults & Brexit + results \\
\hline Brethink & Brexit + rethink \\
\hline brevastation & Brexit + devastation \\
\hline breverse & Brexit + reverse \\
\hline Brexecuted & Brexit + executed \\
\hline Brexhausted & Brexit + exhausted \\
\hline Brexin & Brexit + in \\
\hline brexistence & Brexit + existence \\
\hline Brexistential (crisis) & Brexit + existential (crisis) \\
\hline Brexodus & Brexit + exodus \\
\hline Brexpats & Brexit + expats \\
\hline brexpert & Brexit + expert \\
\hline Brexplosion & Brexit + explosion \\
\hline brexshit & Brexit + shit \\
\hline Brextraneous & Brexit + extraneous \\
\hline Brextrovert & Brexit + extrovert \\
\hline Brintrovert & Brexit + introvert \\
\hline brollocks & Brexit + bollocks \\
\hline brugger off & Brexit + bugger off \\
\hline debression & depression + Brexit \\
\hline in-bretween & in-between + Brexit \\
\hline regrexit & regret + Brexit \\
\hline
\end{tabular}


brex-/bre-/br- is highly recognizable in blends is further evidence that brexit is firmly established and institutionalized in the English lexicon.

Blends coined with source words other than Brexit include: Brentry [Britain/British + entry], the word coined retrospectively by analogy with Brexit to denote the entry of the UK into the European Economic Community in 1973; beleave [believe + leave], a slogan urging people to believe in the leave vote; EUge (mistake) [EU + huge], used by those opposed to Brexit to describe the EU referendum results; Eurhope [Europe + hope], EUnity [EU + unity] and EUthanasia [EU + euthanasia], all three seen on placards on pro-EU demonstrations.

With the possible exception of compounds, which we do not include in this paper, other wordformation processes have proved far less frequent. A number of neoclassical compounds have been recorded: Brexitography, Brexitometer, Brexitology and Brexitophobia, but we suspect there must be a few that have escaped us. As for conversion, three nouns have been turned into verbs: bregret, brexit and regrexit. The verb brexit has been used in a clipped form brex, as in 'Don't go brexin' my heart', a play on a popular song. Bregret, brexit and bremain have so far been used as bases for suffixations: bregret $>$ bregretter; brexit $>$ brexiter, brexiteer, Brexitesque; bremain $>$ bremainer. Although outside the present corpus, we must mention outer, which predates brexiter as a term for someone who is in favour of the UK leaving the EU. Finally, we find Brexies as an example of embellished clipping (as defined by Bauer \& Huddleston, 2002).

\section{Brexit as an inspiration}

As already shown by the examples where Brexit was used as a model word, this explosion of linguistic creativity was not limited to the coining of words directly related to the UK and the EU referendum, nor was it limited to the use of Brexit as a pattern. Triggered by the political events but also by the lexical inventiveness surrounding them, other lexical bases were also put to use to coin humorous names for possible similar events in various other countries. As can be seen from Table 3, they are again mostly portmanteaus.

The flood of new coinages inspired by and/or modelled after Brexit and the speed with which they are still multiplying is fascinating. What may account for such speed in reacting linguistically to a political event and why the speakers of English have so readily embraced the chance to
Table 3: Hypothetical scenarios of other countries leaving the EU, inspired by Brexit

\begin{tabular}{|c|c|}
\hline Byegium & [bye + Belgium $]$ \\
\hline Caleavefornia & [California + leave $]$ \\
\hline Czechout & [Czech + checkout] \\
\hline Departugal & [depart + Portugal] \\
\hline Italeave & {$[$ Italy + leave $]$} \\
\hline Oustria & [oust + Austria] \\
\hline Quitaly & [quit + Italy] \\
\hline Retireland & [retire + Ireland] \\
\hline Slovakout & {$[$ Slovakia + out $]$} \\
\hline Texodus & [Texas + exodus $]$ \\
\hline
\end{tabular}

manifest their linguistic creativity is discussed in the next section.

\section{Linguistic creativity}

Benczes $(2009$, 2010) offers a detailed account of the reasons for linguistic creativity. Although her discussion focuses on creativity in metaphorical and metonymical compounding, Benczes's classification of the various types of motivation underlying the appearance of novel compounds in English may be useful for explaining and accounting for creativity with which Brexit has triggered a myriad of novel forms.

Speaking of novel compounds, Benczes provides several types of motivation for linguistic creativity: compactness and vividness; context (communicative, textual, cultural, social); memorability (see also Bauer, 1983); analogy; remotivation; and multiple motivation. Of those factors that may motivate linguistic creativity, especially important for our analysis of Brexit-induced neologisms are compactness and vividness, social context and analogy. Compactness, closely related to language economy, is based on the Minimax Principle, which, according to Brekle (1978, quoted in Benczes, 2009: 52), allows the speaker 'to minimize the surface complexity of the utterance while at the same time [the speaker] aims to maximize the information that is communicated to the hearer'. Compounds, in other words, 'are able to express complex ideas in a compact, wordlike form (as opposed to expressing the same idea with a longer phrase)' (Benczes, 2009: 53). Compactness results in vividness, since, for example, regrexit evokes a much more vivid 
image than its longer explication as 'regretting the decision to vote for Britain leaving the EU', as this new word suggestion is defined in the Collins Dictionary. ${ }^{5}$ As far as Brexit-induced neologisms are concerned, immediate social context played a crucial role in their formation. As already attested in literature, the political and social setting frequently induces the coinage of new words (for the coinage of euphemisms see GradečakErdeljić, 2005; see also Benczes, 2009, 2010 for examples of newly formed compounds induced by the social context). Therefore, linguistic creativity is not 'simply an act of mind; it is also a contextual act', as Carter (2007: 598) convincingly points out. Brexit, as a major event in British and European history, together with all the controversy surrounding it, is a prime example of a political event which is easily prone to the formation of new coinages. As for analogy, another 'influencing factor with regard to the emergence of creative compounds' (Benczes, 2009: 60), a close analysis of Brexit-induced neologisms confirms that ' $[t]$ he analogical principle can account for much of the ability of people to interpret and form new combinations; they simply make appropriate substitutions in previously learned combinations used as exemplars' (Lamb, 1998: 265, as quoted in Benczes, 2009: 60). Put simply, 'other speakers and writers create similar forms by analogy simply because it is fashionable to do so; they want to show that they, too, are trendy, creative, and cool' (Lehrer, 2007: 116). This is attested by some of the examples in our corpus such as Gerxit, Frexit, Texit, etc., which have been readily formed according to analogy with Brexit.

\section{Conclusion}

Serving as a spark for an explosion of neologisms, Brexit as a political event has in a very short period of time provoked linguistic creativity par excellence, which has, according to our material, been mainly demonstrated by the pervasiveness of blends. Moreover, the creativity demonstrated by English speakers has activated a word formation schema causing the secretion of a new word formation element (Brexit itself), which is a rare case of a blend being used for the coining of other blends, mainly due to the low level of recognisability of such newly coined blends from blends. Without intending to speculate on the number of neologisms in our data which will remain in the English language, we may conclude by saying that the word Brexit has already made an impact on the English lexicon and, judging by the fact that it has relatively quickly reached a high level of conventionalization, lexicalization and institutionalization, more neologisms may be expected as new political and economic developments surrounding the process of Britain's exiting the EU continue to unfold.

\section{Acknowledgement}

The second author acknowledges funding received by the project of the Ministry of Education, Science and Technological Development of the Republic of Serbia no. 178002 Languages and Cultures in Time and Space.

\section{Notes}

1 The definition was subsequently modified to reflect the post-Brexit reality: 'The withdrawal of the United Kingdom from the European Union' (Oxford Dictionaries, 2016).

2 This hypothetical scenario was also called drachmageddon [drachma + armageddon] as Greece would have returned to the drachma, its national currency, while the crisis in Spain has been dubbed Spanic [Spain + panic] and Spailout [Spain + bailout], and a general word for the demise of the Eurozone, a Eurogeddon [Euro (zone) + armageddon]. For more examples of portmanteaus denoting apocalyptic economic scenarios, see Lalić-Krstin (2016: 174-265).

3 This word-coining trend has spread to other languages as well, as evidenced, for instance, by several Serbian coinages, humorously and somewhat paradoxically referring to Serbia leaving the EU when it is not even a member of the EU: Sexit, Srexit, Srbende (combining Serbian and German elements, Srbija + Ende), and perhaps the most creative and symbolic of all, Srbinjet (combining Srbija with njet, transcription of the Russian word for 'no').

4 Initial capitalization is kept as in the sources.

$5 \mathrm{http}: / /$ www.collinsdictionary.com/submission/ 17506/regrexit

\section{References}

Algeo, J. 1977. 'Blends, a structural and systemic view'. American Speech, 52(1-2), 47-64.

Aronoff, M. 1976. Word Formation in Generative Grammar. Cambridge, MA: MIT Press.

Bauer, L. 1983. English Word-Formation. Cambridge: CUP.

Bauer, L. 1994. Watching English change: An Introduction to the Study of Linguistic Change in Standard Englishes in the Twentieth Century. Harlow: Longman.

Bauer, L. \& Huddleston, R. 2002. 'Lexical word formation'. In R. Huddleston \& G. K. Pullum (eds.), The Cambridge Grammar of the English Grammar. Cambridge: CUP, pp. 1621-1721.

Benczes, R. 2009. 'What motivates the production and use of metaphorical and metonymical compounds?' In M. Brdar, M. Omazić \& V. Pavičić Takač (eds.), Cognitive Approaches to English. Fundamental, Methodological, 
Interdisciplinary and Applied Aspects. Newcastle upon Tyne: Cambridge Scholars Publishing, pp. 49-67.

Benczes, R. 2010. 'Setting limits on creativity in the production and use of metaphorical and metonymical compounds'. In A. Onysko \& S. Michel (eds.), Cognitive Perspectives on Word Formation. Berlin and New York: Mouton de Gruyter, pp. 219-242.

Bryant, M. M. 1974. 'Blends are increasing'. American Speech, 49(3-4), 163-184.

Cambridge Dictionary. 2016. Online at <http://dictionary. cambridge.org/> (Accessed June-November 2016).

Cannon, G. 1986. 'Blends in English word formation'. Linguistics 24(4), 725-753.

Cannon, G. 2000. 'Blending'. In G. Booij et al. (eds.), Morphologie: Eininternationales Handbuchzur Flexion und Wortbildung/Morphology: An International Handbook on Inflection and Word-Formation. Berlin and New York: Walter de Gruyter, pp. 952-956.

Carter, R. 2007. 'Response to Special Issue of Applied Linguistics devoted to Language Creativity in Everyday Contexts'. Applied Linguistics, 28(4): 597-608.

Collins. 2017. Online at $<$ https://www.collinsdictionary. $\mathrm{com} />$ (Accessed July 15, 2017).

Crystal, D. 1995. The Cambridge Encyclopedia of the English Language. Cambridge: CUP.

Farmer, S. 2016. 'No 'Brexit' for Andy Murray, who wins second Wimbledon title in 4 years'. Los Angeles Times, July 10, 2016. Online at http://www.latimes.com/sports/lasp-wimbledon-mens-final-20160710-snap-story.html (Accessed July 14, 2017).

Fontaine, L. 2017. 'The early semantics of the neologism BREXIT: A lexicogrammatical approach'. Functional Linguistics 4(1): article 6. Online at $<$ https://link.springer. com/content/pdf/10.1186\%2Fs40554-017-0040-x.pdf $>$ (Accessed March 7, 2017).

Gradečak-Erdeljić, T. 2005. 'Euphemisms in the language of politics or how metonymy opens one door but closes the other'. In P. Cap (ed.), Pragmatics Today. Frankfurt a. M., Berlin and Bern: Peter Lang, pp. 287-299.

Katamba, F. 1994. English Words. London and New York: Routledge.

Kemmer, S. 2003. 'Schemas and lexical blends'. In H. Cuyckens et al. (eds.), Motivation in Language. Amsterdam and Philadelphia: John Benjamins, pp. 69-97.

Lalić-Krstin, G. 2016. 'Morfemizacija krnjih leksičkih osnova u savremenom engleskom jeziku: leksikološki i leksikografski aspekti [Morphemization of truncated lexical bases in present-day English: lexicological and lexicographic aspects]'. PhD thesis. Novi Sad: University of Novi Sad.

Lehrer, A. 2006. 'Neologisms'. In K. Brown (ed.), Encyclopedia of Language and Linguistics, $2^{\text {nd }}$ edn. Oxford: Elsevier, pp. 590-593.

Lehrer, A. 2007. 'Blendalicious'. In J. Munat (ed.), Lexical Creativity, Texts and Contexts. Amsterdam and Philadelphia: John Benjamins Publishing Company, pp. 115-133.

Leyland, C. 2016. 'Brexit enters the OED'. Online at $<$ http:// blog.oxforddictionaries.com/2016/12/brexit-enters-oed/> (Accessed December 21, 2016).

Liberman, M. 2015a. 'Grexicography'. Online at $<$ http:// languagelog.ldc.upenn.edu/nll/?p=19609> (Accessed July 7, 2016).

Liberman, M. 2015b. 'Point of no Breturn'. Online at $<$ http:// languagelog.ldc.upenn.edu/nll/?p=26514> (Accessed July 7, 2016).

Liberman, M. 2016. 'OtherCountries_ExitFromTheEU: better portmanteaux'. Online at $<$ http://languagelog.ldc. upenn.edu/n1l/?p=26366> (Accessed July 7, 2016).

Marchand, H. 1969. The Categories and Types of Present-Day English Word-Formation, $2^{\text {nd }}$ edn. München: C. H. Beck'sche Verlagsbuchhandlung.

Maxwell, K. 2016. 'BuzzWord: Brexit'. Online at <http:// www.macmillandictionary.com/buzzword/entries/brexit. html $>$ (Accessed June 28, 2016).

Metcalf, A. 2002. Predicting New Words: The Secrets of Their Success. Boston and New York: Houghton Mifflin. OED. 2017. Online at <http://www.oed.com/view/Entry/ 54763375> (Accessed July 15, 2017).

Oxford Dictionaries. 2016. Online at $<$ https://www.oxford dictionaries.com/>. (Accessed June-November 2016).

Quinion, M. 2013. 'Brexit'. World Wide Words, February 2, 2013. Online at $<$ http://www.worldwidewords.org/ turnsofphrase/tp-bre2.htm> (Accessed May 30, 2015).

Szymanek, B. 2005. 'The latest trends in English word-formation'. In P. Štekauer \& R. Lieber (eds.), Handbook of Word-Formation. Dodrecht: Springer, pp. 429-448.

Štekauer, P. 2002. 'On the theory of neologisms and nonce-formations'. Australian Journal of Linguistics, 22(1), 97-112.

Zwicky, A. 2016. 'Leaving, in tears and a portmanteau'. Arnold Zwicky's Blog. Online at $<$ https://arnoldzwicky. org/2016/06/25/leaving-in-tears-and-a-portmanteau/> (Accessed November 10, 2016). 